\section{A CASE STUDY ON URBAN LAND USE AND DISASTER RISKS IN BRAZIL}

\author{
José Rubens Morato Leite ${ }^{1,2,3}$, Larissa Verri Boratti ${ }^{1,2,3}$, Fernanda Salles Cavedon-Capdeville ${ }^{1,2,3}$, \\ Kleber Isaac Silva de Souza ${ }^{4}$, Kaliu Teixeira ${ }^{5,3}$, Jose Irivaldo Alves Oliveira Silva ${ }^{6,3 *}$, Valeriana Augusta \\ Broetto $^{1,3,7}$, Marina Demaria Venâncio ${ }^{1,2,3}$, Tônia Andrea Dutra ${ }^{1,3}$, Eduardo Lima Bastos ${ }^{8,3}$, Maria \\ Leonor Codonho $^{1,3}$, Heidi Michalski ${ }^{1,2,3}$, Natanael Dantas ${ }^{1,3}$, Luiz Fernando Rossetti Borges ${ }^{1,3}$, \\ Humberto Filipi ${ }^{1,2,3}$, Leatrice Faraco Daros ${ }^{1,3}$, Elisa Fiorini Beckhauser ${ }^{1,3,7}$, Eduarda Muccini ${ }^{1,3}$, Filipe \\ Bellincanta de Souza ${ }^{3,9}$ y Larissa Bischoff ${ }^{1,3}$
}

\section{ABSTRACT}

In the context of a climate emergency, cities are vulnerable territories prone to several disaster risks of different nature. Latin American cities are especially vulnerable, with high rates of urbanization and severe socio-environmental problems. Within this scenario, this paper aims at addressing strategies for disaster risk reduction (DRR) with emphasis on those risks potentially intensified by climatic changes, focusing on the Brazilian urban space. To look at these linkages contextually, a case study was carried out. This comprises the case of a drainage basin located in an urban area in Brazil (the city of Florianópolis, State of Santa Catarina). Drawing on the case study, the paper examines the existing interaction between sectoral policies for urban land use, climate change and DRR by analysing a set of international documents and Brazilian domestic law and policy frameworks selected at all governance levels (national, state, and municipal). Furthermore, it explores the availability and accessibility of official data related to the area under study in terms of disasters events, climate risks, demography of the affected populations and environmentally protected areas. Finally, it sheds light on the role of cartography, in particular of risk maps, in the coordination of land use rules and DRR policies.

\section{KEYWORDS}

Disaster risk reduction, Climate change, Land use rules, Territorial justice, Cartography, Brazil

\section{UN ESTUDIO DE CASO SOBRE EL USO DEL SUELO URBANO Y LOS RIESGOS DE DESASTRES EN BRASIL}

\section{RESUMEN}

En el contexto de una emergencia climática, las ciudades son territorios vulnerables propensos a varios riesgos de desastres de diferente naturaleza. Las ciudades latinoamericanas son especialmente vulnerables, con altas tasas de urbanización y graves problemas socioambientales. En este contexto, este trabajo aborda las estrategias para la reducción del riesgo de desastres (RRD) con énfasis en aquellos riesgos intensificados por los cambios climáticos, centrándose en el espacio urbano brasileño. Para observar estos vínculos, se llevó a cabo un estudio de caso: la cuenca hidrográfica ubicada en un área urbana de Brasil - Florianópolis. El artículo examina la interacción existente entre las políticas sectoriales para el uso del suelo urbano, el cambio climático y la RRD mediante el análisis de documentos internacionales y la legislación nacional y los marcos de políticas seleccionados en todas las áreas de gobernanza. Además, explora la disponibilidad y accesibilidad de datos oficiales en términos de eventos de desastres, riesgos climáticos, demografía de las poblaciones afectadas y áreas ambientalmente protegidas. Finalmente, arroja luz sobre el papel de la cartografía, en particular de los mapas de riesgo, en la coordinación de las reglas de uso del suelo y las políticas de RRD.

\section{PALABRAS CLAVES}

Reducción del riesgo de desastres, Cambio climático, Reglas de uso de tierra, Justicia territorial, Cartografía, Brasil
1. Federal University of Santa Catarina (UFSC), Florianópolis, Brazil.

2. Coordination for the Improvement of Higher Education Personnel Foundation (CAPES), Brasilia, Brazil.

3. Environmental Law and Ecological Politics Research Group (GPDA), Florianópolis, Brazil.

4. Brazilian Institute of Environment and Renewable Natural Resources (IBAMA), Brasilia, Brazil.

5. Urban Planning Institute of Florianópolis (IPUF), Florianópolis, Brazil.

6. Federal University of Campina Grande (UFCG), Campina Grande, Brazil.

7. National Council for Scientific and Technological Development (CNPq), Brasilia, Brazil.

8. Professional Association of Geographers of Santa Catarina (APROGEO), Florianópolis, Brazil.

9. Pontifical Catholic University of Paraná (PUCPR), Curitiba, Brazil.

*Autor de correspondencia: irivaldo.cdsa@gmail.com

DOI:

https://doi.org/10.55467/ reder.v6i1.92

\section{RECEIVED}

15 May 2021

\section{ACCEPTED}

13 July 2021

PUBLISHED

1 January 2022

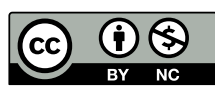

All articles published in REDER follow an Open Access policy and are supported by a CreativeCommons Attribution-NonCommercial 4.o International License.

Journal of Latin American Studies on Disaster Risk Reduction (REDER) 


\section{INTRODUCTION}

In the context of a climate emergency, cities are vulnerable territories prone to climate-related disaster risks under all dimensions - socially, economically, and environmentally, as well as in relation to infrastructure safety (World Bank, 2010). On the one hand, despite covering less than $2 \%$ of the Earth's surface, cities contribute to climate change with $76 \%$ percent of the global carbon dioxide emissions and with a significant part of greenhouse gas emissions (UN Habitat, 2019). On the other hand, however, cities are also strongly hit by related harmful effects. In 2018, 59\% percent of the cities with at least 500,000 inhabitants were under high risk of exposure to at least one type of disaster (UN DESA, 2018). Considering this in association with studies which project that more than $2 / 3(68 \%)$ of the world population will be living in urban areas by 2050 (UN, 2019), it is urgent to address the linkages between urban planning, climate change and disaster risk reduction (DRR).

Justice issues also arise for climate change exacerbates and/or creates novel vulnerabilities in the urban space (UN Special Rapporteur on Extreme Poverty and Human Rights, 2019). Dimensions of injustices are related to the unequal exposure to risks and to the unequal capacity to adapt and respond to disasters geographically within the city territory, and demographically within different urban communities and social groups (Masson-Delmotte et. al, 2018). In this regard, LatinAmerican cities are especially impacted. Latin America is one of the most vulnerable regions to climate change (Maplecroft, 2017; Eckstein et al, 2018) and it is the most urbanized region on the planet (UNDESA, 2018). On top of that, Latin-American cities' well-known situation of spatial segregation and socio-environmental precariousness is a key driver for increasing the exposure to and intensifying the adverse impacts of climate change-related disaster risks (UNISDR, 2019). Brazil is an example, a country where 8.3 million people live in risk-prone areas. It is estimated that 6.4 million people were displaced due to disaster events in Brazil between 2000 and 2017, mainly due to hydro-meteorological disasters, such as floods (Folly, 2018).

For governments (nationally, regionally and locally) to satisfactorily respond to such a complex, multi-causal challenge it requires a two-fold approach: (i) coordination of key sectoral policy and regulatory frameworks, (ii) combined with production, access and cross-analysis of reliable official data on the linkages between climate change, disaster events, socio-economic vulnerabilities, land use, and the environment. This is a perspective that already permeates international commitments recently reviewed/agreed under the structure of the United Nations (UN), in particular, for the purpose of this research, the Sustainable Development Goals (2015), the Sendai Framework for Disaster Risk Reduction (2015), the Paris Agreement (2015), and the New Urban Agenda (2016). However, difficulties and uncertainties remain with respect to the implementation of the goals and action plans set out internationally at the national level.

In this scenario, this paper aims to discuss strategies for DRR with a focus on disaster risks potentially intensified by the adverse effects of climate change within the urban space. It does so from an interdisciplinary viewpoint which draws on literature on Law and Geography. The relationship between Law and Geography has been explored under two main dimensions. On the one hand, there is literature that examines how law shapes and legitimizes the spatial order through processes of "spatialization of law" and "legalization of space" (urban theory and legal geography). See, for instance: Blomley et al, 2001. On the other hand, there is literature on a novel scholarship so-called 'Geolaw', which sheds light on the linkages between Law and the technical aspects of Geography (mainly, spatial data infrastructure - IDE, geographic information systems GIS, and cartography) (Ugeda, 2017). To this end, the paper emphasizes the need for coordination between urban planning and land use rules with climate and DRR policies, as well as for the use of cartography and georeferencing instruments. The aim is to reflect, particularly, on how normative elements and technical elements of geoinformation could be articulated in order to contribute to the improvement of law, policy and decision-making processes towards promoting resilience to disasters and achieving climate and territorial justice in the cities.

With the purpose of addressing these linkages contextually, a case study was carried out. This comprises the case of a drainage basin (Saco Grande) located in an environmentally sensitive urban area in Brazil (the city of Florianópolis, State of Santa Catarina). Section 2 (empirical dimension) outlines the objectives of the case study and the methodology developed. Next, drawing on the case study, section 3 (legal dimension) examines the existing interaction (if any and to what extent) between sectoral policies for DRR, climate change, and urban land use. It analyses
Revista de Estudios

Latinoamericanos sobre Reducción del Riesgo de Desastres (REDER)

Design: Lupe Bezzina

Recommended citation (APA style):

Morato Leite, J.R., Verri

Boratti, L., Cavedon-

Capdeville, F.S., Silva de

Souza, K.I., Teixeira, K.,

Oliveira Silva, J.I.A., Broetto,

V.A., Demaria Venâncio,

M., Dutra, T.A., Lima

Bastos, E., Codonho, M.L.,

Michalski, H., Dantas, N., Rossetti Borges, L.F., Filipi,

H., Faraco Daros, L., Fiorini

Beckhauser, E., Muccini,

E., Bellincanta de Souza,

F. \& Bischoff, L. (2022).

A Case Study on Urban

Land Use and Disaster

Risks in Brazil. Revista de

Estudios Latinoamericanos sobre Reducción del Riesgo

de Desastres REDER,

6(1), 156-170. https://doi.

org/10.55467/reder.v6i1.92 
a set of international documents and Brazilian domestic law and policy frameworks selected at all governance levels (national, state, and municipal). Finally, section 4 (technical dimension) explores the availability and accessibility of official data related to the area under study in terms of disasters events, climate risks, demography of the affected populations and environmentally protected areas. Furthermore, it sheds light on the role of cartography, in particular of risk maps, in the coordination of land use rules and DRR policies.

\section{SITUATING THE PROBLEM \\ Presenting the case study}

Seeking to explore contextually the relevance of integrating legal analysis and cartography for the development of DRR policies in the urban space, a case study was carried out. The city of Florianópolis, in southern Brazil (State of Santa Catarina) was selected due to its geographical and urbanization characteristics, for it clearly represents the challenges of integrating DRR, climate, environmental and planning policies. Florianópolis is a coastal city with approximately 500,000 inhabitants, being partially located on an island of great scenic beauty. Its territory comprises coastal ecosystems and protected areas, which are not only particularly vulnerable to negative impacts of climate change, but also suffer intense pressure from tourist activity and rapid urbanization. The urbanization process has resulted in the occupation of risk-prone areas by low-income population, especially hill tops (Florianópolis, 2014). Moreover, flooding records have been reported due to changes in the tidal regime combined with occupation of mangrove areas and coastal erosion, as well as events of intense winds and cyclones. Notably, the state of Santa Catarina is the southern state of Brazil with the largest population residing in risk areas (IBGE, 2018). According to the IPCC, urban areas, particularly coastal ones, are especially vulnerable to climate change, being exposed to thermal stress, storms, continental and coastal floods, landslides, water shortages, sea level rise, and weather tides. Risks intensify when they reach vulnerable communities and areas with poor infrastructure and urban services (IPCC, 2014).

More specifically, the Saco Grande drainage basin was identified within the municipality's territory as the subject matter of study. It is a region that spreads through an area of 1,723.05 ha, out of which $21.6 \%$ are occupied by urban settlements, with a population of 17,932 people (IBGE, 2010). One can find in the region disorderly occupation of sloping areas (spaces specially protected by environmental legislation and where planning legislation prevents land parceling), combined with anthropic factors aggravating risks associated with climate events and disasters. These include vegetation cleansing and poor urban infrastructure, especially lacking sanitation. Furthermore, the mouth of the basin comprises a mangrove area, which performs relevant ecosystem services related to risk reduction and control of the water regime. A conservation unit was established to guarantee its protection (Ecological Station of Carijós, Federal Decree 94,656/1987), however, this area has also suffered pressure from the urbanization process.

The carrying out of the case study aimed at drawing attention, particularly, (i) to the type/ source/quality/accessibility of existing official data in relation to the themes under analysis; (ii) to the importance of presenting territorial, environmental and social information in a geospatial and integrated way for the understanding of normative and socio-environmental and territorial justice aspects that affect a given territory; as well as (iii) to the impact of law and policy, especially local ones, on the prevention (or perpetuation) of territorial and climate injustices in the urban space.

\section{Methodology}

The development of the case study drew on the expertise of a multidisciplinary team including professionals from law, geography, geology, and engineering. This allowed for combining legal analysis with the use of tools related to geographic information systems (GIS). After selecting the case (see section 2.1), the research work evolved into three stages: (i) analysis of policy and legal frameworks applicable, (ii) data collection, and (iii) production of cartography.

Firstly, the Sustainable Development Goals (SDGs) guided the choice for the thematic axes of the legal dimension of research, namely SDG 1 (poverty eradication), SDG 6 (drinking water and sanitation), SDG 11 (cities and sustainable communities), and SDG 13 (action against global climate change). From these, three categories of policy and legal frameworks were subject to analysis: (i) disaster risk reduction; (ii) climate change, and (iii) urban planning and the environment. For each category, a set of international, national, state, and local policies and legislation were selected. Due to space constraints, a detailed exam of these is out of the scope of this paper. In fact, section 3 
summarizes the conclusions steaming from the analysis carried out, which was guided by inquiries in relation to the following: (i) attributions and powers of local governments; (ii) provisions that address concerns with socioeconomic, environmental and territorial vulnerabilities and injustices; (iii) coordination between the thematic-specific law and policy frameworks explored; (iv) alignment of domestic law with international commitments.

Next, the work included gathering statistical and geographic data (demographic, environmental, socioeconomic and on land use) and existing official cartography information for the area under study. Online databases and websites of federal, state, and municipal government agencies were consulted, as well as institutions such as the Public Prosecutor Office, which provided relevant information about administrative and judicial proceedings (environmental sanctions, lawsuits, and land regularization processes). To narrow the data gathering exercise, four key themes were established, namely (i) Environment and Territory, (ii) Risks, (iii) Vulnerabilities and (iv) Conflicts (see Table 01).

\begin{tabular}{ccc} 
Information & \multicolumn{2}{c}{ Type of data } \\
\hline \multicolumn{2}{c}{ Environmental and Territory } \\
\hline water resources & cartographic and documental \\
\hline environmentally protected areas & cartographic and satellite image \\
\hline land use rules & cartographic and legislation \\
\hline risks of disasters & Risks & \\
\hline climate risks & cartographic and documental \\
\hline & Vulnerabilities & documental \\
\hline $\begin{array}{c}\text { vulnerable population (income, traditional } \\
\text { communities, elderly and children) }\end{array}$ & statistical \\
\hline socioeconomic, health and sanitation indicators & statistical \\
\hline Conflicts & documental \\
\hline Administrative sanctions & documental \\
\hline Civil Inquiry & documental \\
\hline Public Civil Action & &
\end{tabular}

Table 1. Data and cartography gathered Source: Authors, 2022.

Finally, cartography material was produced that showcase different layers of the collected data for the same geographic area. This contributed to visualizing and therefore better understanding the extent to which the thematic-specific sectoral policies explored in the research are closely related in practice. To identify the characteristics of the area under study - more specifically, to define the areas occupied by urban settlements -, the researchers accessed satellite images (Figures 1 , 2 , and 3). Then, information available in spatial databases from various sources consulted were crossed through geoprocessing routines involving set operations and Boolean algebra (see Table 02). The results of this are detailed below (section 4).

\begin{tabular}{cl} 
Map & \multicolumn{1}{c}{ Geoinformation } \\
\hline \multirow{3}{*}{ Areas non-susceptible to land parceling } & Occupation by human settlements \\
& Area non-susceptible to land parceling \\
& Conservation areas (Ecological Station of Carijós) \\
\hline \multirow{3}{*}{ Zoning (master plan) in risk-prone areas } & Risk Reduction Municipal Plan \\
& Flooding-prone areas \\
& Master Plan (zoning) \\
\hline \multirow{3}{*}{ Household income in settlements in risk-prone } & Occupation by human settlements \\
areas & Average household income \\
& Risk Reduction Municipal Plan \\
& Flooding-prone areas \\
\hline
\end{tabular}




\section{LEGAL DIMENSIONS: URBAN LAND USE, CLIMATE CHANGE AND DRR \\ Policy and Legal Framework}

The theoretical and conceptual dimensions connected to the subject matter are not ignored. Claims that issues of distributive justice emerge from law and decision-making processes related to the environment and urban-territorial planning have been widely explored through abundant empirical research and literature, especially on the origins of the environmental justice movement and its contextual manifestations (e.g. Bullard, 2000; Taylor, 2000; Walker and Bickerstaff, 2000; Martinez-Alier, 2003; Been, 1993; Arnold, 1999; Lazarus, 1993; Schlosberg, 2009). The notion of territorial justice has also been well-discussed in the context of planning debates (e.g. Lefebvre, 1991; Harvey, 2008; Fainstein, 2010) and of literature in the realm of Law and Geography (e.g. Mitchell, 2003; Blomley, 1994). Furthermore, there is an effort towards interpreting the notion of urban sustainability under a public policy agenda (UN Habitat framework), while climate justice concerns within urban space are at the forefront of recent debates (Lyster, 2016; Robinson, 2018). Ferreira (2017) points out that climate change should be considered in the South American regional context, since changes are already taking place.

However, it is out of the scope of this paper to explore the topic theoretically. In fact, the aim is to examine whether these notions have normative support within the set of law and policy examined, both international and domestic ones. To this end, we investigate the presence of provisions that refer to an agenda of justice in the context of DRR, climate and planning and environmental policies, what includes mainly attention to distributive effects (risks and vulnerabilities associated with poverty and inequality), and special protection for vulnerable groups (and with reduced responsiveness and adaptation capabilities).

\section{Disaster Risk Reduction (DRR)}

As for the DRR approach, the key international document considered was the Sendai 20152030 Framework for Action for Disaster Risk Reduction, which aims to prevent and reduce risks and vulnerability to disasters, strengthening preparedness, response, and reconstruction. Local governments are taken as central actors in the implementation of the Sendai Framework, being responsible for adopting policies, plans and strategies that can contribute to the achievement of the set goals and priorities, mainly through the adoption of a Local Disaster Risk Reduction Strategy. The Sendai Framework is linked to SDG 11 for it reinforces the commitment (i) to make cities resilient and sustainable with a focus on the most vulnerable, and (ii) to promote the integration of DRR, climate change and urban-environmental policies at the local level.

From the linkage between the Sendai Framework and SDG 11, it was possible to identify a number of DRR guidelines related specifically to the case under study and that were used as guidance for the analysis of national, state and municipal policy and legal frameworks. These were, mainly: (i) assessment and production of disaster risk and vulnerability data; (ii) integration of data in the formulation of public policies; (iii) incorporation of DRR into national and local rules and policies, supported by DRR strategies and platforms; (iv) respond to disasters and rebuild better through contingency plans and policies aligned with territorial planning; (v) policies aimed at finding lasting solutions to informal settlements.

In terms of the Brazilian policy and legal framework for DRR, at the federal level the reference is the National Civil Protection and Defense Policy (Federal Law 12,608/2012) and the 20162019 Pluriannual Plan (which aims to articulate development and social inclusion with specific DRR actions). At the state level (Santa Catarina), there is the State System for Civil Defense and Protection - SIEPDEC (Law 15,953/2013) and its regulatory decree (Decree 1,879/2013). SIEPDEC integrates prevention, mitigation, emergency preparedness, response, and recovery actions, as well as attributes municipal powers. The municipality of Florianópolis does not have a comprehensive norm on the subject. What one can find is Municipal Decree 11,494/2013 that creates the Risk Management Commission (CPGRRD). This acts as a coordination tool for actions aimed at reducing risk factors, preparing for coping with disaster situations and strengthening the risk prevention culture. Also, a Municipal Risk Reduction Plan (PMRR) was adopted in 2007, and revised in 2012, which indicates the risk areas within the municipality; however, it actually does not enjoy a legislative character. It is worth mentioning that the Plan indicates the existence of four disaster risk areas in the area under study. 


\section{Climate Law and Policy}

DRR policies and the climate agenda are closely related, being the commitments and goals set out in the Sendai Framework and in the Paris Agreement complementary. Under the global climate agenda, the Paris Agreement is the first universal and legally binding climate agreement aimed at strengthening the capacity of States and the international community to respond to the impacts of climate change through mitigation and adaptation measures, coping with loss and damage that cannot be avoided by financing technology transfer and capacity building. The Paris Agreement encompasses a human-rights approach to climate change, calling on States to respect, promote and take into account their human rights obligations in actions to address climate change. This represents an important step towards incorporating climate justice into climate negotiations (Lyster, 2016). Equally, the climate issue was addressed in SDG 13, which provides for strengthening resilience and capacity to adapt to climate and disaster risks, integrating climate measures into policies, strategies and planning and creating capacities for climate-related planning with a focus on marginalized communities.

With respect to the case study, a set of specific guidelines steaming from the Paris Agreement and the SDG 13 was selected for the analysis of national, state and municipal political-legal frameworks. These are: (i) evaluation and production of data on climate risks and vulnerabilities; (ii) integration of data in the formulation of public policies; (iii) mainstreaming of climate action measures into both national and local norms, policies, plans and programmes; (iv) climate planning with a focus on vulnerable and marginalized communities; ( $v$ ) measures to strengthen resilience and the ability to adapt to climate risks.

In the context of Brazilian law and policy, at the federal level the research looked at the National Policy on Climate Change - PNMC (Law 12,187/2009), as well as at the National Plan for Adaptation to Climate Change - PNA. The latter includes, among the eleven sectors addressed, cities, DRR, vulnerable people and populations, and coastal zones. At the state level, there is the State Policy on Climate Change and Sustainable Development (Law 14,829/2009). When it comes to the local level (the city of Florianópolis), no specific legislation or climate policies were identified. This represents a relevant gap since this is a coastal and island city, facing a high level of exposure to adverse effects of climate change (Marengo et al, 2016). Consequently, the subject is somewhat disregarded within other key and interconnected local policies, especially urban planning.

\section{Planning and Environmental Law and Policy}

To address the planning and environmental law and policy framework, it is key to consider international documents signed to promote sustainable urban development. The most recent initiative is the New Urban Agenda, resulting from the 2016 UN Conference on Housing and Sustainable Urban Development (Habitat III). The New Urban Agenda reinforced previously stated commitments regarding sustainable and fair urbanization based on a human-rights approach. The emphasis is on participatory urban governance and urban-environmental and social justice (equality and non-discrimination in the access to services and urban infrastructure). Notably, in comparison to previous documents, it included mitigation and adaptation to climate change and DRR as strategies to be pursued, with special attention to fostering the capacity of local authorities to do so $(\S 14(\mathrm{c}))$.

According to $\S 13(\mathrm{~g})$ of the Agenda, sustainable cities are those that "approve and implement policies for disaster risk reduction and management, which reduce vulnerability, increase resilience and the capacity to respond to natural and anthropogenic hazards, and that foster adaptation to climate change and its effects". Furthermore, it affirms the commitment to strengthen the resilience of cities by adopting integrated policies and plans in line with the Sendai Framework, and by incorporating a holistic and data-based perspective on DRR, with an emphasis for the most riskprone areas. Special attention is given to the preparation of communities to respond and adapt to risks, especially in marginalized neighborhoods and informal settlements. To this end, it is pivotal to integrate DRR and climate change mitigation and adaptation measures to the planning and management of urban development.

In Brazil, planning in the urban space is an attribution of the municipal government through the issuing of land use rules (mainly the master plan and zoning rules, article 41, Law 10,257/2001). However, this must observe general guidelines established in the national urban development 
policy, in Articles 182 and 183, Federal Constitution, and in Law 10,257/2001, so-called City Statute. These guidelines include the observance of the principle of the socio-environmental function of the property, guaranteeing access to decent housing, enlarging access to essential urban services, and improving urban infrastructure and environmental conditions. In addition, there are also land use restrictions provided for in a broader set of legislation at the federal level, especially those related to limitations imposed on land parceling for environmental reasons or risk control (e.g. water and geological safety), in this regard law 6,766/1979, as well as specific legal regimes pertaining to protected areas. These may prevent parceling and land use, or require specific authorization and the implementation of corrective measures in particular cases. For the purpose of this research, the main rules taken into consideration were the ones applicable to the permanent preservation areas (Law 12,651/2012) and to conservation units (Law 9,985/2000). Although not key to the elaboration of the case study cartography, other legislations were also consulted, for example, the Environmental National Policy (Law 6,938/1981), Water Resources Management National Policy (Law 9,433/1997), and the Sanitation National Policy (Law 11,445/2007). It is also worth mentioning that relevant technical and legal concepts are set by rules issued by the National Council for the Environment (CONAMA).

Importantly, an effort towards integrating DRR to planning and environmental policies was put in place recently in Brazil. This refers to the inclusion among the guidelines for urban policy of the adoption of measures to mitigate and prevent impacts resulting from disasters. In addition, it was added to the mandatory cases for the elaboration of a master plan the case of "cities included in the national register of municipalities with areas susceptible to the occurrence of high impact landslides, sudden floods or related geological or hydrological processes" (article 41(VI), Law 10,257/2001, as amended by Law 12,608/2012).

Considering the above, one can conclude that the Brazilian planning and environmental legal framework at the federal level broadly aligns with the guidelines and commitments stated in the context of international documents on sustainable urban development and on its integration with DRR actions and resilience to climate change. However, at the local level this alignment seems to be weaker, for the linkage between planning and land use rules, DRR measures and climate change mitigation and adaptation does not always operate, as it is the case of the city of Florianópolis. This will be further explored in relation to the case study in section 4 .

\section{Concluding Remarks on the DRR, Climate and Land Use Policy and Legal \\ Frameworks in Relation to the Case Study}

First, there are several rules and policies concerning the themes under study at the national level in Brazil. However, one can conclude that the level of alignment of these with international guidelines is low. This is mainly because most of these rules and policies are prior to the agreement or revision of the international reference documents and they have not been properly updated since. Second, it seems that there has been an effort towards coordinating the different sectoral policies examined, especially planning rules with climate change, DRR and the environment. Key provisions with an intersectoral character can be found in particular in the City Statute, the National Policy for Protection and Civil Defense and the National Adaptation Plan. Nevertheless, these initiatives still demand further development into effective practices and into regional and local detailed regulation. Third, the regional scale under exam (the Brazilian state of Santa Catarina State) is even more limited in this sense. Despite the identification of norms related to the themes subject to analysis (State Policy for Climate Change and State System for Defense and Civil Protection), they are outdated and are not coordinated. In addition, they provide mainly for general rules, with indication of only a few concrete measures that could have an impact on the local level.

Fourth, it is noteworthy that the national guidelines and legal provisions establish attributions for the local authorities in order to incorporate issues related to climate and DRR and socioenvironmental vulnerabilities into planning rules (for example, to prevent and address occupation of risk-prone areas, and to harmonize zoning with protected areas). However, with regards to the locality examined (city of Florianópolis), there remains an important policy and legal gap. This is because the municipality has not issued specific norms about climate and DRR, nor has it incorporated these dimensions into the master plan (although the master plan mentions climate risks as limiting urban growth). Despite the existence of an official map of risk-prone areas, this does not suffice to provide for coordination between the management of these areas and land 
use rules and zoning, or for putting in place measures to avoid the occupation of these areas and to address the situation of communities exposed to risk. In this sense, the case study showed the overlapping of risk-prone areas and the zoning established in the master plan, which indicates a multiplicity of different uses and legal regimes over the same territory not satisfactorily articulated (to be further explored in section 4).

\section{TECHNICAL DIMENSION: USING CARTOGRAPHY TO QUALIFY DECISION-MAKING PROCESSES \\ Cartography produced for the case study}

It is estimated that $80 \%$ of the data currently produced worldwide is somehow combined with a geospatial component (Robinson, 2016). This highlights the relevance of georeferencing and of the regulation of spatial data infrastructure systems and official cartography for strategic governance decisions (Ugeda, 2017). Nonetheless, in addition to discussing regulatory frameworks for SDIs and GIS, with emphasis on the relevance of standardization and sharing of databases, the focus should also be on examining its use to qualify sectorial public policies and decision-making processes. This is the point of intersection between Law and the technicality of Geography within which this research is placed. To explore this from an empirical perspective, this section describes the use of cartography for the case study carried out.

Agenda 21 (United Nations Conference on Environment and Development, 1992) had already indicated the relevance of geospatial data and of its standardization for the implementation of sustainable development strategies (including interoperability and geographic information systems - GIS). In this context, regulations have been established in several jurisdictions, for instance, in the United States (National Spatial Data Infrastructure, 1994) and in the European Union (Directive 2007/2/EC of the European Parliament; Regulation (EC) 1205/2008). In Brazil, there is a constitutional reference to national cartography (Article 21(XV), Federal Constitution), and the National Spatial Data Infrastructure is regulated by Decree $6,666 / 2008$. Other examples of regulation of spatial/territorial information in Brazil are the Multipurpose Territorial Register (Ministry of the Cities Ordinance 511/2009) and the Rural Environmental Register (Law 12,651/2012).

Particularly, the case study here presented sheds light on the need to produce territorial, environmental, and social information combined with quality cartography and geoinformation to guide the planning and assessment of interventions in urban space. This allows for the government, at all planning and decision scales, to exercise more efficiently its role in territorial management, environmental protection, and development control, at the same time as ensuring public data transparency. Moreover, the availability of quality cartography data also allows for the private sector to seek the efficiency of projects in terms of land use, environmental quality and risk assessment; as well as helps any citizen to search for data on quality indicators about the place where they live or to consider vulnerabilities they are subject to. Consequently, publicly available, quality cartography may play a key role in promoting social justice in the urban space.

This section explores the outcomes from the elaboration of cartography in relation to the case study. More specifically, this exercise sought to identify, geographically, situations of socioenvironmental and territorial injustice related to risks of disasters in the urban space in a Brazilian city through the use of maps. For this purpose, a set of key information was cross-analysed and layered, including zoning restrictions and norms for land parceling (both urban and environmental), the official mapping of risk-prone areas, and the average household income.

In addition to restrictions established by the municipal zoning, federal and state planning legislation also prevent land parceling in areas with slopes steeper than $30 \%$. Federal environmental legislation (Federal Law 4,771/1965 and 12,651/2012) also prevents the use and occupation of land in protected areas ("areas of permanent preservation") in marginal strips of water courses or hillsides steeper than $100 \%\left(45^{\circ}\right)$ and the suppression of vegetation in areas of restricted use between slopes of $46 \%\left(25^{\circ}\right)$ and $100 \%$.

Considering the planning and environmental restrictions indicated above and the conservation unit located within the region under study, only 350.16 ha $(20.3 \%)$ of the territory would be susceptible to land parceling. This number may be even lower, as other types of especially protected areas whose identification requires detailed field analysis were not considered (such as mangrove ecosystems and 'restingas' and their transitional areas). Even so, available data shows 126.14 ha $(33.8 \%)$ of urban settlements located in places that are not susceptible to land parceling (Figure 1). 


\section{UNSUCCESSIBLE AREAS TO THE SOIL INSTALLMENT}

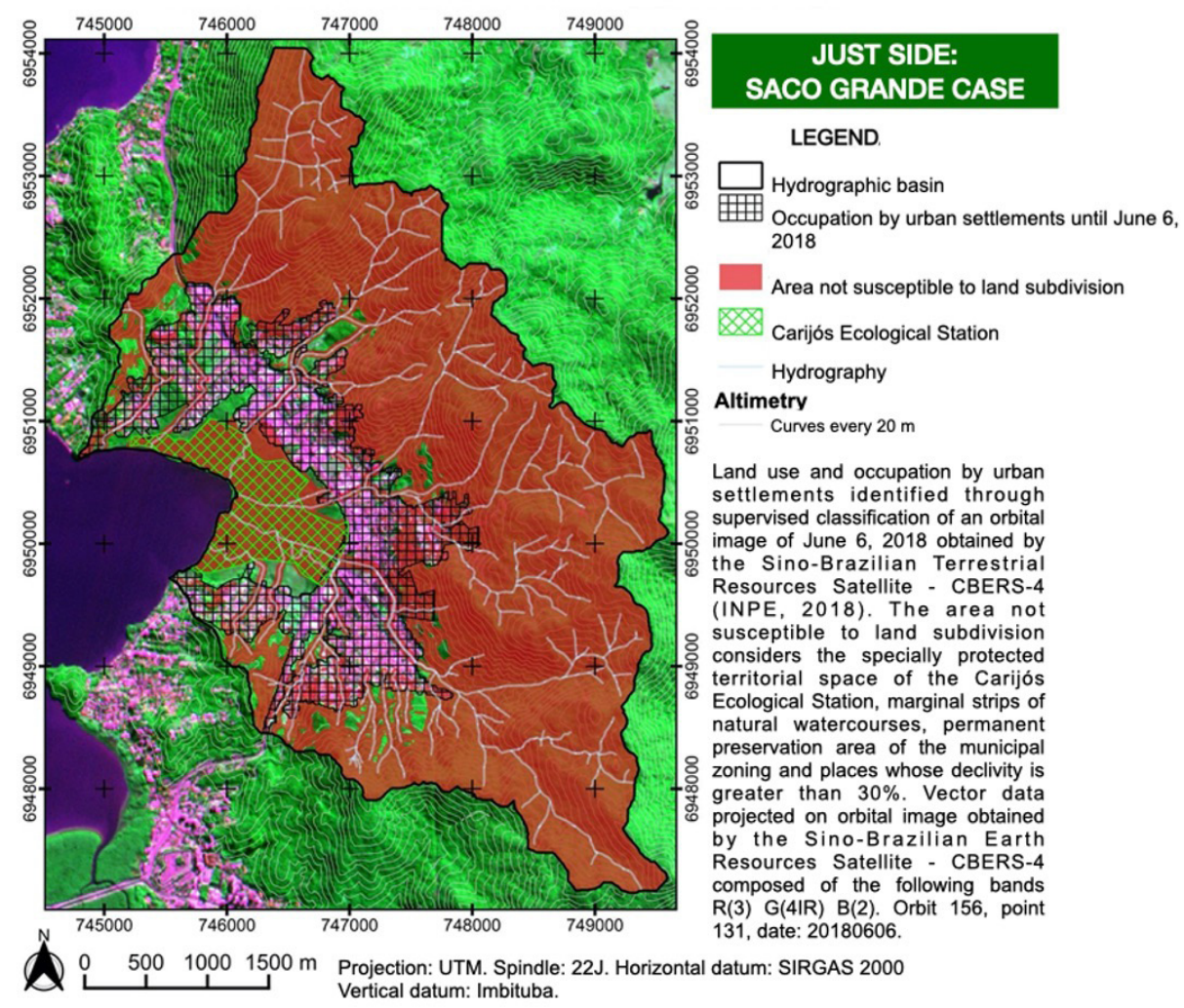

Figure 1. Land use and occupation by urban settlements in the Saco Grande hydrographic basin and areas insusceptible to land parceling due to the slope, presence of a fully protected conservation unit, municipal zoning and marginal strips of natural watercourses.

Source: Authors, 2022

With the purpose of correlating the territory actually occupied by urban settlements with riskprone areas, two official documents were consulted: (i) the Municipal Risk Reduction Plan - including sites at risk of flash flooding, landslides and block rolling -, and (ii) the Letter of Susceptibility to Gravitational Mass Movements and Flooding - including sites at risk of flooding or silting (CPRM 2013; 2015). From these, it seems that, although the city of Florianópolis has a Risk Reduction Plan in place and has elaborated cartography identifying areas susceptible to flooding, stilting and landslide, the zoning rules (2014 master plan) are permissive to residential, commercial or mixeduse occupation over areas defined as at risk (Figure 2). At least, a portion of 55.93ha of low-income urban settlements in an at-risk area is defined as Social Interest Zone (ZEI) for the purpose of applying special planning legal tools that allow for the government to regularize urban occupation.

The socioeconomic profile of the population in the area under study was also taken into consideration. In Brazil, low-income populations are those whose monthly household income is equal to or less than five minimum wages. The values of the average monthly household income available in the census database (IBGE, 2010) were classified according to the value of the minimum wage at the time of writing $(\mathrm{R} \$ 1.100,00)$.

From the combined analysis of territorial data with data from the latest census carried out (IBGE, 2010), one can observe a well-defined pattern of occupations in risk-prone areas according to household income. In areas on hillsides and subject to significantly more catastrophic events, such as landslides, block bearings and flash floods, low-income population predominates (Figure 3). Coincidentally, these are settlements located up the slopes or at their base, where urban land is cheaper or is under restrictions. According to the Municipal Risk Reduction Plan (2014), these areas feature disordered occupation, buildings with low construction standards and poor urban infrastructure (mainly deficient sanitation and a non-existent drainage system).

On the other hand, occupations with higher household income are found inland or close to the coastal plain, in places with higher real estate value. The predominant risk in these areas is flooding, as they are located within the deposition area of hillside water courses, within tidal flats (restinga and mangrove ecosystems), and in places of low declivity and elevation (subject to increased risk of flooding by meteorological tides). 
ZONING THE MASTER PLAN IN RISK AREAS

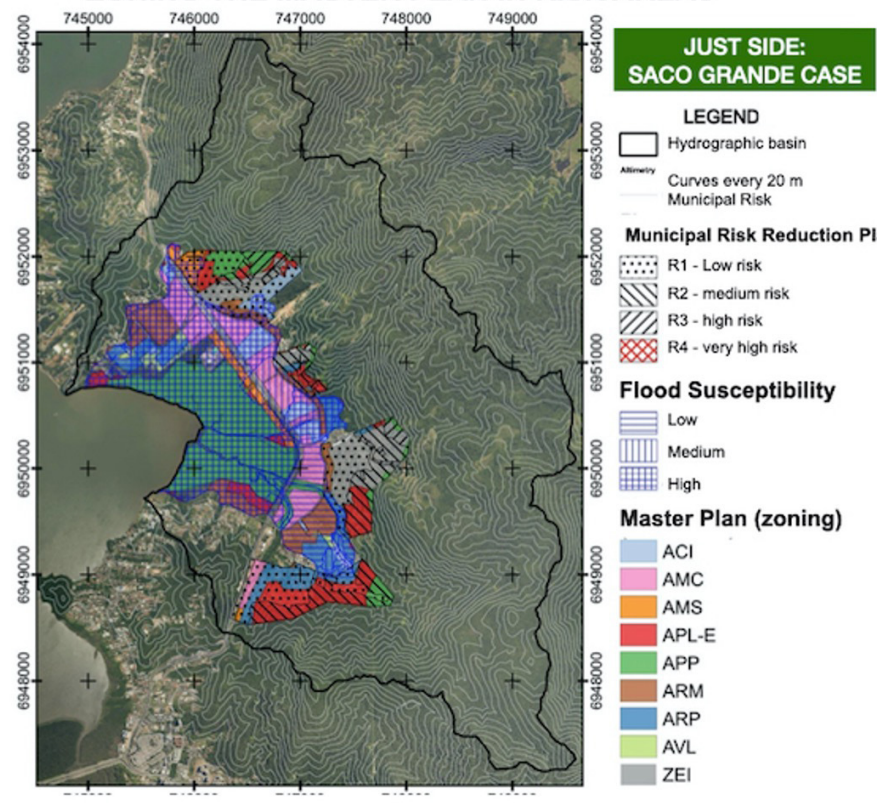

Zoning in the Master Plan of the Municipality of Florianópolis of the risk areas identified in the Municipal Risk Reduction Plan (FLORIANOPOLIS, 2014) and in the Flood Sustainability Letter produced by CPRM $(2013 ; 2015)$. Vector data projected on digital orthophotography from the 2012 Aerophotogrammetric Survey of the State of Santa Catarina.

Q \begin{tabular}{l}
0.500 \\
\hline
\end{tabular} $10001500 \mathrm{~m}$ Projection: UTM. Spindle: 22J. Horizontal datum: SIRGAS 2000

Figure 2. Zoning in the Master Plan of Florianópolis of the risk-prone areas identified in the Municipal Plan for Risk Reduction (FLORIANÓPOLIS, 2014) and in the Letter of Susceptibility to Floods produced (CPRM, 2013; 2015). (CPRM, 2013; 2015).
Source: Authors, 2022, based on data from Florianópolis (2014) and CPRM (2013; 2015). MAP LEGEND: Institutional Community Area (ACI); Central Mixed Area (AMC); Mixed Service Area (AMS); Preservation Area with Limited Use of Slope (APL-E); Permanent Preservation Area (APP); Mixed Residential Area (ARM); Predominant Residential Area (ARP); Green Leisure Area (AVL); Special Areas of Interest (ZEI)

\section{FAMILY INCOME IN SETTLEMENTS SITUATED IN RISK}

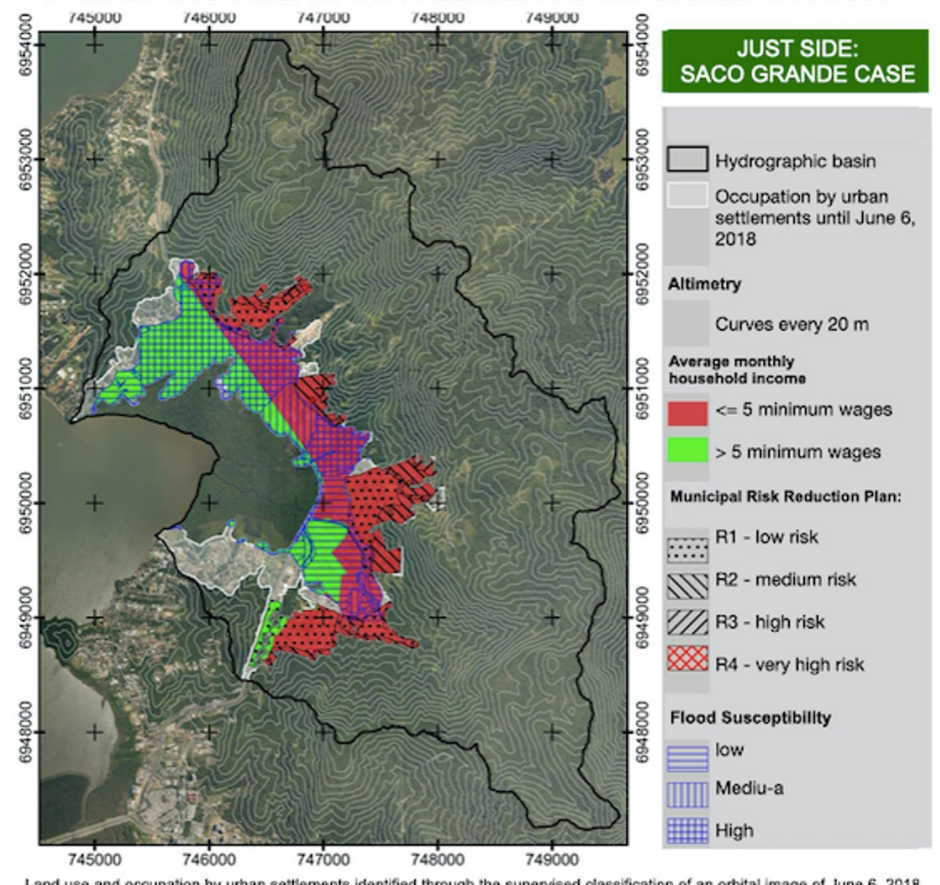

Land use and occupation by urban settements identified through the supervised classification of an orbital image of June 6, 2018 by the 2010 Demographic Census (IBGE, 2010) for the risk areas identified in the Municipal Risk Reduction Plan
by the renthe (FLORIANOPOLS, 2014) and in the Flood Susceptbility Letter produced by CPRM (2013:2015). Minimum wage valu Survey of the state of Santa Catarina.

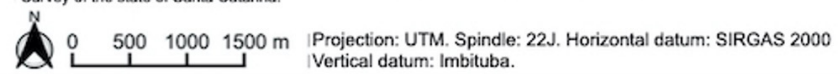

Figure 3. Land use and occupation by urban settlements correlated with the average monthly household income (IBGE, 2010) in the risk-prone areas identified in the Municipal Risk Reduction Plan (FLORIANÓPOLIS, 2014) and in the Letter of Susceptibility to Floods (CPRM 2013; 2015).

Source: Authors, 2022, based on the analysis of land use and occupation rules and data from IBGE (2010), CPRM (2013; 2015) and FLORIANÓPOLIS (2014). 
To conclude, it is possible to observe a strong correlation between the risk of sudden disaster events (landslides, rolling blocks and flash floods) and occupation by low-income population of urban areas where land parceling is not allowed. In areas subject to flooding, occupation is predominantly high-income, and the risk is associated with the occupation of riverbeds and floodplains of water courses, as well as of tidal flats. This raises questions about socio-environmental and territorial justice since it indicates that socio-economic vulnerability and lack of access to urban infrastructure and services contribute to increased exposure to risks and reduced resilience to disasters in the cities.

\section{Concluding remarks on the cartography produced}

The carrying out of the case study also aimed to contribute to the debate about the quality, coordination and accessibility of data produced by official government sources. This is key for critically evaluating the use of spatial data and geographic information systems with the purpose of verifying the existence of any correlation between socio-environmental and territorial injustices and, consequently, for the improvement of policy and legal frameworks.

With respect to the case under analysis, it is worth highlighting that the researchers crosschecked data from various different sources and cartography databases in order to identify aspects of interest - mainly, risk of disasters, socio-economic profile of the affected population, and urban and environmental limitations. This was a major challenge, resulting from the absence of a multipurpose technical register system. Such a register system could generate its own database and/or interconnect several existing record sources, therefore supporting the gathering, compiling, managing, and publicizing of data produced by different government bodies, entities and private ventures.

Furthermore, despite recent advances in the monitoring of data on disaster risk in Brazil, the case study revealed the existence of a gap in relation to disaster events at the local level. This is because although the information system managed by the federal government gathers data on events by state and by municipality, it does not identify its location within the municipal territory. Also, only events that feature as an "emergency" or as "public calamity" are registered with the system. This means that events of a smaller scale, magnitude or severity that can reach risk-prone areas locally are not computed. Moreover, the city of Florianópolis does not compile such type of information digitally or through specific reports. It would be necessary to examine paper files in archives for this purpose. Thus, it was not possible to access official data on any disaster events that could have occurred locally in the area under study. Consequently, this information is missing in the cartography produced. Data for the city of Florianópolis for the period 2015-2019 shows the occurrence of thirteen disaster events: two in 2015 (two of flash floods); two in 2016 (one storm/ strong gale and one hurricane); five in 2017 (two related to coastal erosions, two flash floods, one storm); two in 2018 (two storms); two in 2019 up to October (one flooding and one storm) ${ }^{1}$.

With regards to climate-related risks, no official data was found at the local level. In addition, the Municipal Risk Reduction Plan does not include meteorological and climatological risks, being limited to the analysis and mapping of geological and hydrological ones. This indicates a weak point of the urban-environmental planning and disaster risk monitoring system for a coastal city whose territory is vulnerable to the effects of meteorological tides, coastal erosion, and sea level rise.

Also, socioeconomic indicators in official databases are presented, in general, in an aggregated manner. Access to disaggregated information, especially at the local level, regarding income and vulnerable groups is still limited, since they depend on the municipality's role in the elaboration of multipurpose technical register systems.

Moreover, one of the research aims was to verify whether there was any official data on territorial (either environmental or urban) conflicts taking place in the area under study. To this end, federal, state and municipal environmental bodies enjoying law enforcement attributions were contacted, as well as the Public Prosecutor's Office. It was found that, although there is some sort of recording system of information on environmental assessment studies, sanctions, civil inquiries and lawsuits involving the territory, with the indication of the corresponding address, such information is not, in general, georeferenced. When georeferencing exists (for instance, in the case of federal and state agencies), there is no integration of databases. 
The federal environmental agency (ICMBio) informed the existence of 88 environmental sanctions in relation to the conservation unit for the period 2009-2018, out of which 56 referred to irregular interventions (vegetation cleansing and building); 33 referred to preventing natural restoration; and 21 referred to pollution of water sources. The state environmental agency (IMA) informed the existence of 112 environmental sanctions for the period 2014-2019, out of which 02 referred to pollution of water sources; 02 referred to unauthorized channeling of water streams; 08 referred to unauthorized polluting activities; 01 referred damage to vegetation; 01 referred to irregular mining activity; and 03 referred to irregular discharge of polluting effluents. The local environmental agency (FLORAM) informed the existence of 64 environmental sanctions for the period 2006-2019, out of which 28 referred to vegetation cleansing in protected areas; 31 referred to irregular building; and 04 referred to pollution of water sources. The State Public Prosecutors Office, which is supported by its own SIG, confirmed the existence of 15 ongoing civil inquiries (from 2009 to 2019). From these, 06 are related to irregular intervention (vegetation cleansing or building) in protected areas, and 01 is related to the lack of sanitation infrastructure.

Also, it was possible to conclude that there is conflict between territorial ordering and environmental protection rules in the area. This is based on the significant occurrence of environmental sanctions due to irregular intervention (suppression of vegetation and building) in protected areas, as well as cases related to the lack of sanitation infrastructure. These are actually consequences of the urbanization process of the city: disorderly occupation in environmentally sensitive regions and with accentuated topography, often classified as risk-prone areas. This was considered as sample data (not exhaustive), once the entities consulted provided information regarding different time periods.

Finally, the research aimed to identify processes of urban land regularization underway in the area under study. To this end, it was necessary to identify the existence of consolidated urban occupations, either informally or irregularly established (non-compliant with land parceling norms, Law 6,766/1979) or located within protected areas (non-compliant with environmental restrictions, specially Law 12,651/2012), which could be subject to specific land regularization legal tools (Federal Law 13,465/2017, so-called REURB and REURB-S). However, difficulties were encountered in accessing official information, since there is no specific database coordinated by municipal departments that would be responsible for addressing the matter ${ }^{2}$. Furthermore, land ownership situation in the region is not mapped out. A great number of land registers and deeds have not been updated or combined with topographic survey ${ }^{3}$. Again, another weakness resulting from the absence of an integrated and reliable geographic information system at the local level.

\section{CONCLUDING REMARKS}

Understanding the territory through spatial data and detailed cartography gives support to law, policy, and decision-making, as well as to the implementation of tools for assessing their distributional effects. This paper aimed to demonstrate this by highlighting the linkage between Law and Geography, thus contributing to enhancing a data management culture in the realm of environmental and planning law. To do so, analysis of policy and legal frameworks related to the selected sectoral policies (DRR, climate and urban-environmental) was combined with the carrying out of a case study focused on the production of maps gathering information on disaster risks in a certain urban area in Brazil.

This research effort reassures cartography as an important planning and environmental tool for the management of risk-prone areas. On the one hand, it may perform as a preventative tool, when applied to prevent new settlements in areas that are not susceptible to occupation. On the other hand, it may perform as a prophylactic tool, when used to assist in decision-making related to defining measures towards disaster risk reduction in already consolidated settlements. However, for greater use of cartography, more investment in research is required to regulate the production, storage, and sharing of official geospatial databases through SDI and the use of GIS. It is key to ensure that geospatial data platforms allow for consultation and analysis of information in a simple, transparent, and easily understandable way by the interested party (both decision makers and public). Otherwise, one would remain dependent on the use of complex data processing and analysis techniques for each case under study.

Furthermore, questions arise about the role of law and policy in preventing (or perpetuating) territorial and climate injustices in the urban space, especially at the local level. This is a debate
2. In fact, only one case of irregular land parceling was identified. However, considering the limited data available, it is not possible to affirm others do not exist. Sources consulted: municipal agents, lawsuit no 0380281 45.2006.8.24.0023, and an undertakin agreement (city of Florianópolis and Public Prosecutors Office).

3. Information provided unofficially by the Second Land Registry of the City of Florianópolis. 
widely explored by literature on environmental and territorial justice. Due to the space constraints and to the limited scope of case study carried out, it suffices to consider here that Brazilian law and policy frameworks in relation to DRR, climate change and urban-environmental planning seem to be poorly equipped to face the complex interaction of factors such as increased climate-related risks, socioeconomic and environmental vulnerabilities, and intensified anthropogenic impact on fragile ecosystems in the context of heavily urbanized regions.

Despite some advances in terms of federal legislation, there has been no due update of the main Brazilian legal frameworks after 2015, when significant developments took place in the international agenda with new commitments from the SDGs, Sendai Framework, Paris Agreement and New Urban Agenda. With respect to the state and local spheres, there is also a lack of specific regulation, which makes it difficult to implement legal mechanisms in practice. In addition, greater effort is required to align state and local level law and policy with international guidelines and commitments. Above all, a systemic view regarding the need for integrating the sectoral policies examined seems to be absent, which was identified particularly through the case study.

Finally, the case study outcomes make it evident that, in addition to a regulatory gap, there is also a need for better structured institutions. With respect to the management of key spatial, environmental, and socio-economic data, government departments at all scales struggle to produce and treat information through reliable, quality, and widely accessible databases. In this regard, the 2019 UN report on the Environmental Rule of Law worldwide (UNEP, 2019) indicates that, despite the greater number of international environmental agreements and the wide increase in the issuing of domestic environmental standards since 1972, important gaps remain. Among the various factors associated with the weak implementation of environmental rules, the UN report highlights the lack of coordination between environmental agencies and their reduced institutional capacity. The insights drawn from the case study here presented corroborate the conclusions of the UN report.

\section{ACKNOWLEDGMENTS}

This article was based on results of research carried out in the Research Group on Environmental Law and Tax Society (GPDA), in the master's and doctorate in Law at the Federal University of Santa Catarina (UFSC), Brazil (Just Side Project).

\section{REFERENCES}

Arnold, Craig Anthony. 1999. "Planning Milagros: Environmental Justice and Land Use Regulation". Denver University Law Review, v. 76, no. 1.

Been, Vicki. 1993. "What's Fairness Got to Do with It? Environmental Justice and the Siting of Locally Undesirable Land Uses”. Cornell Law Review, v. 78, no. 78: 1001-85.

Blomley, Nicholas, David Delaney, \& Richard T. Ford (eds). 20o1. Legal Geographies Reader: Law, Power and Space. Wiley-Blackwell Oxford.

Bullard, R. Doyle. 20oo. Dumping in Dixie: Race, Class, and Environmental Quality. Colorado: Westview Press.

Eckstein, David, Marie-Lena Hutfils, \& Maik Winges. 2018. Global Climate Risk Index 2019: who suffers most from extreme weather events? Weather-related loss events in 2017 and 1998 to 2017. Germanwatch e.V.

Fainstein, Susan S. 2010. The Just City. Cornell University Press.

Ferreira, Ximena Cardozo. 2017. Inundações urbanas: propostas para uma gestão do risco com foco na prevenção de danos. Dissertação de Mestrado. Universidade Vale do Itajaí.

Folly, Maiara. 2018. Migrantes Invisíveis: a crise de deslocamento forçado no Brasil. Artigo Estratégico, Instituto Igarapé.

Harvey, David. 2008. Social Justice and the City. University of Georgia Press.

Instituto Brasileiro de Geografia e Estatística IBGE. 2010. Censo Demográfico 2010. IBGE.

Instituto Brasileiro de Geografia e Estatística IBGE \& Centro Nacional de Monitoramento e Alerta de Desastres. 2018. Populações em Áreas de Risco no Brasil. Técnico, Rio de Janeiro. 
Instituto de planejamento urbano de Florianópolis IPUF. 2002. Levantamento aerofotogramétrico de 2002: cartas planialtimétricas. IPUF.

Intergovernmental Panel on Climate Change IPCC. 2014. Fifth Assessment Report (AR5). IPCC. http:// www.ipcc.ch/report/ar5/

Lazarus, Richard J. 1993. Pursuing 'Environmental Justice': The Distributional Effects of Environmental Protection. Northwestern University.

Lefebvre, Henri. 1991. The Production of Space. Wiley-Blackwell.

Lyster, Rosemary. 2016. Climate Justice and Disaster Law. Cambridge University Press.

Maplecroft, Verisk. 2017. Climate Change Vulnerability Index. Verisk Maplecroft.

Marengo, Jose A, et al. 2016. Impacto, vulnerabilidade e adaptação das cidades costeiras brasileiras às mudanças climáticas: Relatório Especial do Painel Brasileiro de Mudanças Climáticas. Painel Brasileiro de Mudanças Climáticas.

Martinez-Alier, Joan. 2003. The Environmentalism of the Poor: A Study of Ecological Conflicts and Valuation. Edward Elgar Publishing.

Mitchell, Don. 2003. The Rigth to the City: Social Justice and the Fight for Public Space. Guilford Press.

Oficina de las Naciones Unidas para la Reducción del Riesgo de Desastres UNISDR. 2019. Memórias VI Plataforma Regional para la Redución del Riesgo de Desastres en las Américas. UNISDR.

Revi et. al. 2014. “Urban Áreas”. En Intergovernmental Panel on Climate Change (ed.), Climate Change 2014 - Impacts, Adaptation and Vulnerability: Regional Aspects". Contribution of Working Group II to the Fifth Assessement Report of the Intergovernmental Panel on Climate Change. 535-612. IPCC.

Robinson, Cordula. 2016. How You Can Use Geographic Information Technology. Entrevista por Lauren Landry, Março, Northeastern's Master of Professional Studies in Geographic Information Technology (GIT) Program, Northeastern University. https://www.northeastern.edu/graduate/blog/ geographic-information-technology/

Robinson, Mary. 2018. Climate Justice: Hope, Resilience, and the Fight for a Sustainable Future. Bloomsbury Publishing.

Serviço Geológico do Brasil. 2013. Carta de Suscetibilidade a Movimentos Gravitacionais de Massa e Inundações: Município de Florianópolis. CPRM.

Schlosberg, David. 2009. Defining Environmental Justice: Theories, Movements, and Nature. Oxford University Press.

Taylor, Dorceta E. 200o. "The Rise of the Environmental Justice Paradigm: Injustice Framing and the Social Construction of Environmental Discourses”. American Behavioral Scientist, v. 43, no. 4 : 508-80.

The World Bank. 2010. "Cities and Climate Change: an urgent agenda". Open Knowledge Papers, Urban Development Series, no. 10. http://hdl.handle.net/10986/17381

Ugeda, Luiz. 2017. Direito Administrativo Geográfico. Fundamentos na Geografia e na Cartografia Oficial do Brasil. Geodireito.

United Nations UN. 2019. World Urbanization Prospects 2019. Population Division, United Nations.

United Nations UN. 2016. Report of the open-ended intergovernmental expert working group on indicators and terminology relating to disaster risk reduction. General Assembly Report, United Nations.

United Nations UN. 2015. Transforming our World: the 2030 Agenda for Sustainable Development Resolution adopted by the General Assembly on 25 September 2015. UN. http://www.un.org/ga/ search/view_doc.asp?symbol=A/RES/70/1\&Lang=E

United Nations Department of Economic and Social Affairs UNDESA. 2018. The World's Cities in 2018. Population Division, UNDESA.

United Nations Human Rights Council. 2019. Climate Change and Poverty - Report of the Special Rapporteur on Extreme Poverty and Human Rights (A/HRC/41/39). United Nations.

UN Habitat. 2019. Climate Change. UN-Habitat. https://unhabitat.org/topic/climate-change

UNEP. 2019. Environmental Rule of Law: First Global Report. UNEP. 
Delmotte, V. et al. 2018. IPCC: Summary for Policymakers. In: Global Warming of $1.5^{\circ} \mathrm{C}$. An IPCC Special Report on the impacts of global warming of $1.5^{\circ} \mathrm{C}$ above pre-industrial levels and related global greenhouse gas emission pathways, in the context of strengthening the global. World Meteorological Organization.

Walker, Gordon. P., \& Harriet Bulkeley. 2006. "Geographies of Environmental Justice”. Geoforum, v. 37, no. 5: $655-59$. 